Cahiers $d u$ MONDE RUSSE

\section{Cahiers du monde russe}

Russie - Empire russe - Union soviétique et États indépendants

$46 / 4 \mid 2005$

L'invention d'une politique humanitaire

\title{
Barbara Falk, Sowjetische Städte in der Hungersnot 1932/33
}

\section{Gijs Kessler}

\section{(2) OpenEdition}

\section{Journals}

Electronic version

URL: https://journals.openedition.org/monderusse/6618

DOI: $10.4000 /$ monderusse. 6618

ISSN: $1777-5388$

\section{Publisher}

Éditions de l'EHESS

\section{Printed version}

Date of publication: 1 December 2005

Number of pages: $916-918$

ISBN: 2-7132-2057-2

ISSN: $1252-6576$

\section{Electronic reference}

Gijs Kessler, "Barbara Falk, Sowjetische Städte in der Hungersnot 1932/33", Cahiers du monde russe [Online], 46/4 | 2005, Online since 29 June 2009, connection on 03 September 2022. URL: http:// journals.openedition.org/monderusse/6618 ; DOl: https://doi.org/10.4000/monderusse.6618

This text was automatically generated on 3 September 2022

All rights reserved 


\title{
Barbara Falk, Sowjetische Städte in der Hungersnot 1932/33
}

\author{
Gijs Kessler
}

\section{REFERENCES}

Barbara FALK, Sowjetische Städte in der Hungersnot 1932/33. Staatliche

Ernährungspolitik und Städtisches Alltagsleben. Cologne, Weimar, Vienne : Böhlau

Verlag, 2005, XVIII-445 p., index, tabl. (Beiträge zur Geschichte Osteuropas, 38)

1 The 1932/33 famine in the Soviet Union, which carried away the lives of an estimated six to eight million people, has always been studied primarily as a rural cataclysm, tragic consequence of the forced collectivisation of agriculture and the ensuing confrontation between the Bolshevik leadership and the peasantry. The general validity of this emphasis notwithstanding, the famine did, however, not remain exclusively confined to the rural areas. In Sowjetische Städte in der Hungersnot 1932/33 Barbara Falk describes the urban side, primarily in terms of the protracted breakdown of the state rationing system for the non-agricultural population which was in place during those years. Rationing of a whole range of food and non-food consumer items had appeared as a measure to deal with shortages which raised their head in the course of the change-over from the New Economic Policy of the 1920s to the state-led investment and industrialisation drive of the first five-year plan (1928-32). By far the most important of these items were grain and bread, also at the heart of the struggle between Bolsheviks and peasants.

2 In the first two out of the four chapters of the book Falk traces the evolution of the rationing system from its inception as an ad hoc measure to remedy the effects on urban food supply of the first grain collection crises of 1927-28 to its final abolition in 1934-35. Point of departure for these chapters is the pioneering work of Elena Osokina who has characterised the system as a "hierarchy of consumption," a system of precisely defined preferential access to scarce goods and services based on the real or 
perceived importance of individuals or certain groups to the industrialisation drive. ${ }^{1}$ Apart from the military, secret police and government officials these were in the very first place those working in the sectors of the economy allotted priority in the framework of the five-year plan, i.e. heavy industry and construction, and in particular, but not exclusively, blue-collar workers in these branches.

Preferential treatment within the rationing system meant inclusion into the so-called first list, which was supplied from resources pooled and redistributed by the centre, whereas persons, social categories and towns with a lower status were supplied from local resources, the accumulation and stockpiling of which could only be started after the central funds had been supplied. Under the conditions of severe overall scarcity which prevailed this entailed a huge difference between the lists in both the quality and the quantity of food allotted on the basis of the ration cards. Although this differential treatment reflected Bolshevik priorities and preferences for certain sections of the population the rationing system did not evolve from a clear-cut ideologically determined blueprint. Rather, as the book painstakingly demonstrates, policy-making in the sphere of supply and allocation of food reserves basically consisted of a continuation of ad hoc decision-making and improvised solutions. This finding adds to a consensus emerging as of late on the profoundly reactive nature of most of Stalinist decisionmaking except in matters of the highest priority.

The focus of the investigation is on the years of crisis, when dwindling food supplies caused the leadership to gradually roll back most of its commitments in the sphere of food supply with the exception of those covering workers in crucial branches of industry in areas of strategic importance, roughly Moscow, Leningrad, the Donbass and a couple of republican level capitals. The mechanism through which this gradual roll-back of the rationing system took place consisted of the constant exclusion of whole categories of people from the central rationing lists and their transfer to either self-support or decentral rationing, the latter of which gradually blended into the former as the accumulation of the priority central rationing funds scooped up the last available resources. Although the first of these series of exclusions already took place in 1931 the process began in earnest after the failure of the 1932 grain collection campaign, which marks the unofficial start of the famine.

Initially, the exclusion of non-working family members and lower-priority workers from the central rationing lists was the main instrument through which the leadership tried to match "demand" to the ever-dwindling supplies. As the crisis deepened in the winter of 1932/33 and even these reduced commitments became increasingly difficult to uphold, the leadership shifted to a policy focused on the rigorous enforcement of the preferential replenishment of centrally redistributed supplies, at the expense of the already extremely thinly stretched regional supply funds. Particularly in the main famine regions of the Ukraine, Kazakhstan and the North Caucasus, where regional resources were practically non-existent, this condemned large swathes of the urban population, who had no access to central rationing, to starvation. In a thorough examination of household budget statistics and mortality figures, many of which procured from archival evidence, the author demonstrates the consequences; a decline in the caloric intake of the population below physical subsistence levels and a corresponding rise in the death rate.

6 The second half of the book is dedicated to what the author calls a "thematic" approach to the famine, largely on the basis of a case study of the city of Kharkov, capital of the 
Ukrainian union republic until 1934, and its hinterland. It is in these two chapters that we find some of the best insights contained in the book.

7 Chapter Three describes the role and adequacy of the various central, decentral and unorganised food supply channels at the local level, partly repeating some of the findings of the preceding two chapters, but adding a valuable section on the so-called "collective farm markets" of those years. Officially condoned by the regime in May 1932 for collective farms and individual collective farmers to directly sell food surpluses to the urban population, during the years of famine they were in practice largely black markets for the resale of goods siphoned off from the rationing system, and as such, Falk argues, a corrective mechanism for the inequalities created by preferential rationing which did not generally save the day, but can have made a crucial difference in many individual cases.

In what is arguably the best part of the book Chapter Four focuses in more detail on the mechanisms of inclusion and exclusion of particular groups and individuals from the rationing system. As the author argues, the basic logic of the process was as banal as brutal. Faced with shortages of bread and the threat of starvation people attempted by all possible means to obtain a rationing card, while at the same time the state did all its best to keep as many people as possible outside the rationing system. One of the first groups to be excluded were non-working family members of blue and white-collar workers on the rationing lists. Soon to follow were seasonal workers and workers in lowpriority branches of industry. Further, the state proceeded to exclude any category of workers who maintained some sort of tie to agriculture, and who was therefore perceived to be able to feed himself. Apart from workers of recent peasant extraction, this wave of exclusions also specifically targeted people who worked in the non-agricultural sector, but lived in the countryside, a sizeable contingent in some areas, particularly where industry was located in the suburbs or outside of towns. Finally, in December 1932 the regime moved to rid the rationing system of workers who violated labour discipline as well as of "parasitic" and "socially alien elements" in a wave of expulsions connected to the introduction of the system of internal passports in that same month. Falk provides important new evidence for the interconnectedness of these two operations.

Together, the successive waves of expulsions reduced the coverage of the rationing system to such an extent that the large majority of the urban population was outside of it. What is more, even most of those inside did not receive rations large enough to cover even the most basic needs. Although the author does not explicitly make this argument, this is an important reminder for historians not to overstate the significance of the rationing system. For most of the years it was in existence, people were still overwhelmingly dependent on their own initiative in securing the basic necessities of life.

It is for this last reason that the book falls short of being the history of the urban famine its title suggests it to be. Such would require a perspective which departs from the household or the individual and charts the different supply channels for food which existed both within the framework of the rationing system and outside of it. Among others this would involve a much less cursory treatment of subsidiary agriculture, and the substance of ties to the village and the agricultural sector. But perhaps most importantly, it would require addressing the psychological dimension of the drama unfolding, both from the point of view of the population and from that of the regime. 
Falk's book does an admirable job of charting the logistics of the food supply crisis of 1932-33, but a famine is much more than a matter of logistics alone.

\section{NOTES}

1. E. A. Osokina, Ierarkhiia potrebleniia: o zhizni liudei $v$ usloviiakh stalinskogo snabzheniia, 1928-1935 gg. (Moscow, 1993); Elena Osokina, Za fasadom "stalinskogo izobiliia." Raspredelenie i rynok $v$ snabzhenii naseleniia $v$ gody industrializatsii, 1927-1941 (Moscow, 1998). 